\title{
BIOMASS YIELD AND CALORIFIC VALUE OF SIX CLONAL STANDS OF Eucalyptus urophylla S. T. Blake CULTIVATED IN NORTHEASTERN BRAZIL
}

\author{
Thiago Cavalcante Gomes Ribeiro de Andrade ${ }^{1 *}$, Nairam Félix de Barros ${ }^{2}$, \\ Luiz Eduardo Dias², Maria Inês Ramos Azevedo ${ }^{3}$
}

*Corresponding author: thiagoa@ufpa.br

\begin{abstract}
The worldwide demand for clean, sustainable energy has increased in recent years. A potential alternative energy source is biomass from nonnative forests, particularly from the genus Eucalyptus spp. in the specific case of Brazil, currently with several selected clonal stands for energy production. Because each stand adapts differently to different environments, specific studies are required in order to evaluate energy production in a given region. The objective of this study is to determine, from among six clonal stands of Eucalyptus urophylla S. T. Blake, which have greater potential for production of biomass and energy in the South Central region of Maranhão (Grajaú). Clonal stands planted at a spacing of $4 \times 3 \mathrm{~m}$ apart were evaluated at age 41 months, distributed in a completely randomized design with five replicates. Each experimental plot consisted of 100 trees. Analysis included determining biomass yield and distribution in each tree portion as well as calorific value of bark and wood components. Out of the six clonal stands, two outdid the others both in biomass yield and in energy generation, surpassing the least yielding stand by up to $27 \%$.
\end{abstract}

Key words: Bioenergy, reforestation, wood energy.

\section{PRODUÇÃO DE BIOMASSA E PODER CALORÍFICO DE SEIS CLONES DE Eucalyptus urophylla S.T.Blake CULTIVADOS NO NORDESTE DO BRASIL}

RESUMO: A demanda mundial por energia limpa e sustentável tem aumentado nos últimos anos. Uma das alternativas é a biomassa, incluindo os plantios florestais, com destaque, no Brasil, para o gênero Eucalyptus spp., que, atualmente, possui diversos clones selecionados para a produção de energia. Em razão da diferença na adaptação dos clones aos diferentes ambientes, há necessidade de estudos específicos para avaliar a produção de energia para determinada região. Objetivou-se, neste estudo, determinar dentre seis clones de Eucalyptus urophylla S. T. Blake analisados, aqueles com maior potencial para a produção de biomassa e energia para a região Centro Sul do Maranhão (Grajaú). Os clones foram avaliados com 41 meses de idade, plantados em espaçamento de $4 \times 3 \mathrm{~m}$, e distribuidos em delineamento inteiramente casualizado, com cinco repetições. Cada parcela experimental era composta por 100 árvores. Foram determinadas a produção e a alocação de biomassa de cada parte da árvore e o poder calorífico de casca e do lenho. Dos seis clones estudados, dois se destacaram tanto na produção de biomassa, quanto para a geração de energia, sendo superiores em até $27 \%$ em comparação com o clone de menor rendimento.

Palavras-chave: Bioenergia, reflorestamento, energia da madeira.

\section{INTRODUCTION}

The energy mix worldwide is primarily based on consumption of fossil fuels, which not only are not renewable but have also been regarded as a major cause of the climate changes on record. That has prompted many countries to reflect on the need for drastic changes, which include intensifying use of other energy resources, particularly renewable resources, including wood (BRITO, 2007).

Use of wood for energy production generates less pollution, if compared to fossil fuels, as it releases less sulfur and as the $\mathrm{CO}_{2}$ emitted into the atmosphere during the burning process of biomass is usually offset by its absorption by newly established stands.

\footnotetext{
${ }^{1}$ Universidade Federal do Pará - Altamira, Pará, Brazil

${ }^{2}$ Universidade Federal de Viçosa - Vicosa, Minas Gerais, Brazil

${ }^{3}$ Universidade Federal do Tocantins - Palmas, Tocantins, Brazil
}

On account of its climate and soil conditions as well as land availability, Brazil features among the countries with greatest potential for energy production from biomass. The country boasts 520 million hectares of native forests and around 6.5 million hectares of nonnative forests, out of which $74.8 \%$ correspond to eucalyptus crops (ASSOCIAÇÃO BRASILEIRA DE PRODUTORES DE FLORESTAS PLANTADAS - ABRAF, 2012; ORGANIZACIÓN DE LAS NACIONES UNIDAS PARA LA AGRICULTURA Y LA ALIMENTACIÓN FAO, 2011). In 2007 alone, the Brazilian forest sector accounted for $3.5 \%$ of the Gross Domestic Product (GDP) and created 4.6 million direct and indirect jobs. Overall exports of products from nonnative forests reached US\$ 6.1 billion, out of which 70\% resulted from eucalyptus

Cerne, Lavras, v. 19, n. 3, p. 467-472, jul./set. 2013 
(LERAYER, 2008). In 2011, R $\$ 7.6$ billion was collected in taxes (ABRAF, 2012), accounting for around $0.51 \%$ of total taxes collected by the Brazilian treasury.

In Maranhão state, the total area planted with eucalyptus forests has increased drastically in recent years, rising from 60,745 ha in 2005 to 165,717 ha in 2011 (ABRAF, 2012), with a portion of the timber output being destined for production of charcoal for ironworks, an example of which is the company G5 Agropecuária (Grupo Ferroeste).

The company G5 Agropecuária cultivates eucalyptus in the municipalities of Grajaú and Barra do Corda to supply ironworks located in Açailândia. Other than soil conditions and climate, another factor that may affect biomass yield and distribution as well as the quality of timber used for charcoal production is genetic variability among the clonal stands of eucalyptus being used (LELES et al., 2001; SCHUMACHER, 1998).

As far as charcoal production is concerned, the density and calorific value of the source wood are critical factors for successful selection of clones for crop planting. Energy efficiency in the combustion process is conditional on moisture content and the chemical composition of the source wood, noting that concentrations of cellulose, hemicellulose, lignin, extractives and mineral substances will vary according to the species or genotype being used (OLIVEIRA, 1982). With eucalyptus being a high-yielding genus cultivated in many regions of Brazil and its wood being extremely versatile, it may fulfill part of the energy requirements of Brazil (BARCELLOS et al., 2005) and has been used for energy purposes in various applications, including brick making, grain drying, and by ironworks and pulp and paper plants.

This study aimed to analyze the potential of six clonal stands of Eucalyptus urophylla S. T. Blake, evaluating the yield and distribution of biomass for energy generation, under the specific soil and climate conditions of the municipality of Grajaú (MA).

\section{MATERIAL AND METHODS}

\subsection{Environmental conditions}

Experimental plots were installed in an area of Yellow Latosol owned by G5 Agropecuária, a company located in the municipality of Grajaú (MA) $\left(05^{\circ} 50^{\prime}\right.$ to $05^{\circ} 55^{\prime}$ south latitude, and $45^{\circ} 35^{\prime}$ to $45^{\circ} 30^{\prime}$ west longitude), at an altitude of $164 \mathrm{~m}$ above sea level. The average annual temperature is $28^{\circ} \mathrm{C}$, while relative humidity ranges between $72 \%$ and $76 \%$. Average annual rainfall ranges between 700 and 1,300 mm (MARANHÃO, 2007, 2009).

\subsection{Experimental design and field data collection}

This study used six clonal stands of Eucalyptus urophylla S. T. Blake at age 41 months, in January 2010. The experiment was laid out in a completely randomized design with five replicates, each plot consisting of 100 plants of each relevant clone, at a spacing of $4 \times 3 \mathrm{~m}$ apart.

All trees were measured in each plot to obtain the $\mathrm{CBH}$ (circumference at breast height), then values were averaged. Only one tree was felled in each plot, and the criteria was to select the tree whose $\mathrm{CBH}$ was closest to the computed average and whose stem was the most upright, taking the following measurements: total height, commercial height (up to where the diameter with bark is no less than $5 \mathrm{~cm}$ ), leaf weight, branch weight, disc weight as obtained from stem portions $0 \%, 25 \%, 50 \%, 75 \%$ and $100 \%$, bark weight and wood weight as obtained by the difference between stem and bark (Figure 1).

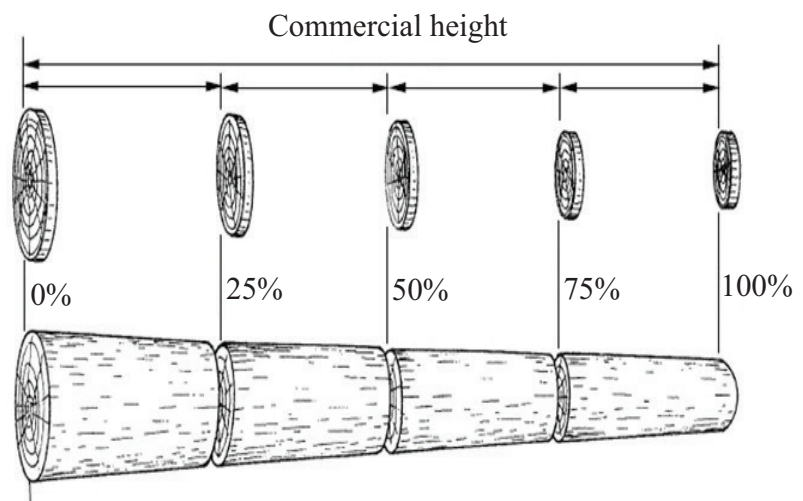

Figure 1 - Stem divided into the following portions: $0 \%, 25 \%$, $50 \%, 75 \%$ and $100 \%$, considering the commercial height.

Figura 1 - Segmento do tronco dividido em base, $25 \%$, 50\%, $75 \%$ e $100 \%$ da altura comercial.

Source: Miranda (2000)

Fonte: Miranda (2000)

Determination of dry matter weight of each component (leaf, branch, bark and wood) was done according to the procedure described by Soares et al. (2007).

\subsection{Sample handling}

Once the fresh weight of the plant material was determined, samples were placed in paper bags and dried in a forced air oven at $70^{\circ} \mathrm{C}$ to a constant weight. They were then weighed again to determine the dry matter weight. With these data, calculations were made of dry matter

Cerne, Lavras, v. 19, n. 3, p. 467-472, jul./set. 2013 
weight per tree component and total dry matter weight, followed by calculations of biomass yield per hectare.

Subsamples of bark and wood were taken from all discs and then submitted to the Wood Energy Laboratory of UFV, for determination of higher calorific values, according to procedures described in ABNT NBR 8633 standard (ASSOCIAÇÃO BRASILEIRADE NORMAS TÉCNICAS - ABNT, 1984), using an adiabatic bomb calorimeter.

For each clonal stand, an estimate was computed of energy generated in one hectare of crop $\left(\mathrm{Mcal} \mathrm{ha}^{-1}\right)$, by multiplying biomass $\left(\mathrm{t} \mathrm{ha}^{-1}\right)$ by higher calorific value $\left(\mathrm{kcal} \mathrm{kg}^{-1}\right)$.

Data were subjected to analysis of variance and means were compared by the Tukey test at the 5\% significance level, with processing and analysis of data being done using statistical software ASSISTAT 7.5 beta.

\section{RESULTS AND DISCUSSION}

\subsection{Biomass yield and distribution}

The clonal stands differed as to the amount of biomass yielded, total and per tree compartment (Table 1). Clonal stand three yielded the highest total biomass, although it did not differ statistically from stands one, four and five. The breadth of range was $20.12 \mathrm{t} \mathrm{ha}^{-1}$, between clonal stands three and six, which corresponds to a difference of $27 \%$. However, the strategy of biomass distribution to different compartments did vary between stands. Stand four, in second position regarding total biomass yield, had the least amount of canopy biomass at the time of evaluation, due to fewer, probably thinner branches, which suggests better adaptation of that clonal stand to the site (GOLFARI; PINHEIRO NETO, 1970).

In order to derive higher yields of total biomass and stem biomass, a clonal stand has to commit a substantial amount of energy to producing leaves. Clonal stand four did not produce much leaf biomass (Table 1). Therefore, its second position regarding total biomass possibly resulted from greater leaf efficiency in absorbing energy, or else that clonal stand would have shed most of its leaves later on. In general, stem is the tree compartment most commonly used for energy generation. Clonal stands three and four yielded the largest biomass amount, accumulating 64.2 $\mathrm{tha}^{-1}, 26.3 \%$ more than the least yielding clonal stand six. Differences between genetic materials of eucalyptus as to volume yield and/or weight yield have been attributed to varying adaptability to local conditions, though without identifying the reasons. Biomass accumulation is a result of greater or more effective capture of growth-inducing resources such as water, nutrients and/or solar radiation.

Regarding biomass distribution in the compartments wood and stem, clonal stand four provided the highest values, $82.46 \%$ and $90.68 \%$ respectively, while clonal stand five, the lowest, $76.23 \%$ and $83.39 \%$ (Table 2). Again, this is indicative of the yield efficiency (total biomass/leaf biomass) of clonal stand four. No statistical difference was found between clonal stands regarding biomass distribution in the bark compartment.

Table 1 - Biomass ${ }^{1 /}$ (dry matter) of clonal stands of Eucalyptus urophylla in the region of Grajaú (MA).

Tabela 1 - Biomassall (matéria seca) de plantios clonais de Eucalyptus urophylla na região de Grajaú - MA.

\begin{tabular}{|c|c|c|c|c|c|c|c|}
\hline \multirow{3}{*}{ Clonal stand } & \multicolumn{7}{|c|}{ Component } \\
\hline & Leaf & Branch & Canopy & Bark & Wood & Stem & Shoots \\
\hline & -----. & & & $\left(\mathrm{t} \mathrm{ha}^{-1}\right)$ & & & \\
\hline 1 & $3.76 \mathrm{ab}$ & $5.92 \mathrm{a}$ & $9.68 \mathrm{ab}$ & $5.75 \mathrm{a}$ & $52.52 \mathrm{ab}$ & $58.27 \mathrm{a}$ & $67.95 \mathrm{ab}$ \\
\hline 2 & $2.77 b$ & $5.57 \mathrm{a}$ & $8.34 \mathrm{abc}$ & $4.17 \mathrm{ab}$ & $49.95 \mathrm{ab}$ & $54.12 \mathrm{ab}$ & $62.46 \mathrm{bc}$ \\
\hline 3 & $4.69 \mathrm{a}$ & $5.49 \mathrm{ab}$ & $10.18 \mathrm{a}$ & $5.77 \mathrm{a}$ & $58.47 \mathrm{a}$ & $64.24 \mathrm{a}$ & $74.42 \mathrm{a}$ \\
\hline 4 & $3.57 \mathrm{ab}$ & $3.00 \mathrm{~b}$ & $6.57 \mathrm{c}$ & $5.82 \mathrm{a}$ & $58.39 \mathrm{a}$ & $64.21 \mathrm{a}$ & $70.78 \mathrm{ab}$ \\
\hline 5 & $4.69 \mathrm{a}$ & $6.30 \mathrm{a}$ & $10.99 \mathrm{a}$ & $4.73 \mathrm{ab}$ & $50.82 \mathrm{ab}$ & $55.55 \mathrm{ab}$ & $66.54 \mathrm{ab}$ \\
\hline 6 & $3.10 \mathrm{~b}$ & $3.89 \mathrm{ab}$ & $6.99 \mathrm{bc}$ & $4.02 b$ & $43.28 b$ & $47.30 \mathrm{~b}$ & $54.30 \mathrm{c}$ \\
\hline Mean & 3.76 & 5.03 & 8.79 & 5.04 & 52.24 & 57.28 & 66.08 \\
\hline $\mathrm{F}^{2 /}$ & $* *$ & $* *$ & $* *$ & $* *$ & $* *$ & $* *$ & $* *$ \\
\hline $\mathrm{CV}^{3 /}$ & 18.08 & 25.42 & 15.65 & 16.96 & 10.26 & 9.6 & 8.98 \\
\hline
\end{tabular}

$1 /$ means of five trees per clonal stand; $2 / * *$ significant at $1 \% ; 3 /$ coefficient of variation $(\%)$.

Cerne, Lavras, v. 19, n. 3, p. 467-472, jul./set. 2013 
Table 2 - Compartmentalization of biomass ${ }^{1 /}$ in clonal stands of Eucalyptus urophylla in the region of Grajaú (MA).

Tabela 2 - Compartimentação de biomassal/ em plantios clonais de Eucalyptus urophylla na região de Grajaú - MA.

\begin{tabular}{ccccccc}
\hline \multirow{2}{*}{$\begin{array}{c}\text { Clonal } \\
\text { stand }\end{array}$} & Leaf & Branch & $\begin{array}{c}\text { Canopy } \\
\text { \% }\end{array}$ & Bark & Wood & Stem \\
\hline 1 & $5.55 \mathrm{abc}$ & $8.71 \mathrm{a}$ & $14.26 \mathrm{a}$ & $8.48 \mathrm{a}$ & $77.26 \mathrm{~b}$ & $85.74 \mathrm{~b}$ \\
2 & $4.44 \mathrm{c}$ & $8.99 \mathrm{a}$ & $13.43 \mathrm{a}$ & $6.70 \mathrm{a}$ & $79.87 \mathrm{ab}$ & $86.57 \mathrm{~b}$ \\
3 & $6.28 \mathrm{ab}$ & $7.35 \mathrm{ab}$ & $13.63 \mathrm{a}$ & $7.79 \mathrm{a}$ & $78.58 \mathrm{ab}$ & $86.37 \mathrm{~b}$ \\
4 & $5.08 \mathrm{bc}$ & $4.24 \mathrm{~b}$ & $9.32 \mathrm{~b}$ & $8.21 \mathrm{a}$ & $82.46 \mathrm{a}$ & $90.68 \mathrm{a}$ \\
5 & $7.12 \mathrm{a}$ & $9.49 \mathrm{a}$ & $16.61 \mathrm{a}$ & $7.16 \mathrm{a}$ & $76.23 \mathrm{~b}$ & $83.39 \mathrm{~b}$ \\
6 & $5.64 \mathrm{abc}$ & $7.24 \mathrm{ab}$ & $12.88 \mathrm{ab}$ & $7.44 \mathrm{a}$ & $79.68 \mathrm{ab}$ & $87.12 \mathrm{ab}$ \\
\hline $\mathrm{Mean}^{2}$ & 5.68 & 7.67 & 13.36 & 7.63 & 79.01 & 86.64 \\
$\mathrm{~F}^{2 /}$ & $* *$ & $* *$ & $* *$ & $\mathrm{~ns}$ & $* *$ & $* *$ \\
$\mathrm{CV}^{3 /}$ & 16.36 & 25 & 14.29 & 16.51 & 2.77 & 2.2 \\
\hline
\end{tabular}

$1 /$ means of five trees per clonal stand; $2 / * *$ significant at $1 \%$, ns not significant; 3 / coefficient of variation ( $\%)$.

Differences between genetic materials of eucalyptus as to their biomass yield and distribution have been reported by several authors (LELES et al., 2001; MOLICA, 1992; NEVES, 2000; SCHUMACHER, 1998; SILVA et al., 2004). Where stands are older than four years, the order of magnitude of biomass distribution very often decreases from wood to leaves. Bark is usually the second compartment in matter weight, though in some cases the quantity of branches is larger, as was reported by Leles et al. (2001) for E. camaldulensis at around 52 months in the cerrado of Minas Gerais, with $10.59 \%$ corresponding to branches and $8.62 \%$, to bark.

Biomass percentage in the canopy compartment will depend on site conditions, genetic material and stand age, and values reported range from $3.44 \%$ for E. urophylla at around 108 months (NEVES, 2000) to $22.3 \%$ for $E$. benthamii at 48 months (SILVA et al., 2004). Means found in this study for canopy and stem were respectively $13.36 \%$ and $86.64 \%$ (Table 2), similar to results found in Minas Gerais (FARIA et al., 2008). Clonal stand four accumulated more biomass (90.68\%) in the stem compartment (Table 2).

\subsection{Higher calorific value}

Higher calorific value (HCV) was slightly higher in the wood compartment than in the bark compartment, in all clonal stands (Table 3). Clonal stand three had the highest
Table 3 - Higher calorific value ${ }^{1 /}$ of bark and wood for Eucalyptus urophylla in the region of Grajaú (MA).

Tabela 3 - Poder calorifico superior ${ }^{l /}$ da casca e do lenho de Eucalyptus urophylla na região de Grajaú-MA.

\begin{tabular}{cccc}
\hline & \multicolumn{3}{c}{ Component } \\
\cline { 2 - 4 } Clonal stand & Bark & Wood & Wood \\
& $--------k^{-1}$ Mcal ha $^{-1}$ \\
\hline 1 & $4,324.00 \mathrm{~b}$ & $4,589.00 \mathrm{ab}$ & $241.00 \mathrm{ab}$ \\
2 & $4,371.75 \mathrm{ab}$ & $4,560.75 \mathrm{~b}$ & $227.80 \mathrm{ab}$ \\
3 & $4,448.50 \mathrm{a}$ & $4,630.50 \mathrm{a}$ & $270.75 \mathrm{a}$ \\
4 & $4,432.25 \mathrm{a}$ & $4,589.50 \mathrm{ab}$ & $268.00 \mathrm{a}$ \\
5 & $4,404.25 \mathrm{a}$ & $4,552.75 \mathrm{~b}$ & $231.40 \mathrm{ab}$ \\
6 & $4,401.75 \mathrm{ab}$ & $4,553.00 \mathrm{~b}$ & $197.05 \mathrm{~b}$ \\
\hline $\mathrm{Mean}^{2}$ & $4,397.08$ & $4,579.25$ & 239.33 \\
$\mathrm{~F}^{2 /}$ & $* *$ & $* *$ & $* *$ \\
$\mathrm{CV}^{3 /}$ & 0.91 & 0.5 & 10.27 \\
\hline
\end{tabular}

$1 /$ means of five trees per clonal stand; $2 / * *$ significant at $1 \%$; 3 / coefficient of variation ( $\%)$.

$\mathrm{HCV}$, both for bark and for wood, and was significantly different from clonal stand one for bark and also from clonal stands five and six for wood.

Clonal stand six was found to be the least suitable for use as an energy source among all clonal stands, as it provided the most reduced calorific value for the wood component, $197.05 \mathrm{Mcal} \mathrm{ha}^{-1}$, which is $27.22 \%$ less than clonal stand three.

$\mathrm{HCV}$ values found for wood in this study are of similar magnitude to results reported for other forest species by Barros et al. (2010), who cited the following as potential energy sources on account of their HCV: Azadirachta indica, with $4,088.5 \mathrm{kcal} \mathrm{kg}^{-1}$, Acacia decurrens (five years old), with $4,550 \mathrm{kcal} \mathrm{kg}^{-1}$, and $E$. grandis (ten years old), with $4,790 \mathrm{kcal} \mathrm{kg}^{-1}$.

Castro (2011) found for E. urophylla $\mathrm{x}$ E. grandis and $E$. urophylla, at ages three, four, five and seven years, mean HCV values of 4,633 kcal kg-1, 4,660 kcal kg-1 and $4,542 \mathrm{kcal} \mathrm{kg}^{-1}$ for the wood component. Oliveira et al. (2010) found a HCV of 4,630 kcal kg-1 for E. pellita at age five years. Quirino et al. (2004) found three HCV values for E. urophylla, 4,595 $\mathrm{kcal} \mathrm{kg}^{-1}, 4,480 \mathrm{kcal} \mathrm{kg}^{-1}$ and 4,422 $\mathrm{kcal}$ $\mathrm{kg}^{-1}$. Foelkel (2008) reported that $\mathrm{HCV}$ ranged from 4,400 $\mathrm{kcal} \mathrm{kg}^{-1}$ to $4,600 \mathrm{kcal} \mathrm{kg}^{-1}$ for species of Eucalyptus spp.

Calonego et al. (2005), Couto et al. (1984) and Pereira et al. (1999) reported that the HCV of wood 
without bark was higher than for bark specifically, in studies respectively with $E$. saligna at age 8.5 years, $E$. dunnii at 14 years and $E$. grandis, similarly to findings in this study (Table 3). This was probably due to the presence of mineral compounds (ashes) in larger quantities in the bark component than in the wood component, noting that ash contributes negatively to calorific value results (CASTRO, 2011).

For purposes of energy generation, clonal stands three and four, respectively with 270.80 and $268.00 \mathrm{Mcal}$ $\mathrm{ha}^{-1}$, are the most desirable, for their biomass and HCV of the wood component, resulting in a gain of around $27 \%$ if compared to clonal stand six, the least desirable for energy generation purposes in the region of Grajaú, due to having the lowest $\mathrm{HCV}$ among all clonal stands (Table 3).

\section{CONCLUSIONS}

Clonal stand four proved the most effective in terms of wood yield, given the smaller amount of canopy biomass.

Clonal stands differed as to biomass yield and distribution and also as to calorific value of bark and wood, noting that clonal stands three and four are the most desirable for cultivation in the study region.

Further studies are required, especially exploring harvest age, in order to better evaluate the potential of biomass yield and distribution and also the calorific value of clonal stands, since this study addressed clonal stands of the same age.

\section{REFERENCES}

\section{ASSOCIAÇÃO BRASILEIRA DE NORMAS TÉCNICAS.}

NBR 8633: carvão vegetal: determinação do poder calorífico. Rio de Janeiro, 1984. 13 p.

ASSOCIAÇÃO BRASILEIRA DE PRODUTORES DE FLORESTAS PLANTADAS. Anuário estatístico da ABRAF 2012: ano base 2011. Brasília, 2012. 150 p.

BARCELlOS, D. C.; COUTO, L. C.; MÜller, M. D.; COUTO, L. O estado da arte na qualidade da madeira de eucalipto para produção de energia: um enfoque nos tratamentos silviculturais. Biomassa \& Energia, Viçosa, v. 2, p. 141-158, 2005.

BARROS, S. V. S.; NASCIMENTO, C. C.; AZEVEDO, C. P.; PIO, N. S.; COSTA, S. S. Avaliação do potencial energético das espécies florestais Acacia auriculiformis e Ormosia paraensis cultivadas no município de Iranduba/Amazonas.

Madera y Bosques, Xalapa, v. 15, n. 2, p. 59-69, 2010.

BRITO, J. O. O uso energético da madeira. São Paulo:

Sociedade Brasileira de Silvicultura, 2007.

CALONEGO, F. W.; SEVERO, E. T. D.; PERRECHIL, M. V. A.; REZENDE, M. A.; LATORRACA, J. V. F. Efeito da vaporização no poder calorífico de Eucalyptus grandis. Floresta e Ambiente, Rio de Janeiro, v. 12, p. 32-37, 2005.

CASTRO, A. F. N. M. Efeito da idade e de materiais genéticos de Eucalyptus sp. na madeira e carvão vegetal. 2011. 86 p. Dissertação (Mestrado em Ciência Florestal) Universidade Federal de Viçosa, Viçosa, 2011.

COUTO, H. T. Z.; BRITO, J. O.; TOMAZELLO FILHO, M.; CORRADINI, L.; FAZZIO, E. C. M. Quantificação de resíduos florestais para produção de energia em povoamentos de Eucalyptus saligna. Instituto de Pesquisa e Estudos Florestais, Piracicaba, v. 26, p. 19-23, 1984.

FARIA, G. E.; BARROS, N. F.; CUNHA, W. P.; MARTINS, I. S.; MARTINS, R. C. C. Avaliação da produtividade, conteúdo e eficiência de utilização de nutrientes em genótipos de Eucalyptus spp. no Vale do Jequitinhonha, MG. Ciência Florestal, Santa Maria, v. 18, p. 369-379, 2008.

FOELKEL, C. E. B. Os eucaliptos e as leguminosas: parte 01, Acacia mearnsii. Porto Alegre: Eucalyptus Online Book \& Newsletter, 2008. 87 p.

GOLFARI, L.; PINHEIRO NETO, F. A. Escolha de espécies de eucalipto aptas para diferentes regiões do Brasil. Brasil Florestal, Rio de Janeiro, v. 1, n. 3, p. 3-23, 1970.

LELES, P. S. S.; REIS, G. G.; REIS, M. G. F.; MORAIS, E. J. Crescimento, produção e alocação de matéria seca de Eucalyptus camaldulensis e E. pellita sob diferentes espaçamentos na região de cerrado, MG. Scientia Forestalis, Piracicaba, v. 59, p. 78-87, 2001.

LERAYER, A. (Coord.). Guia do eucalipto: oportunidades para um desenvolvimento sustentável. São Paulo: Conselho de Informações sobre Biotecnologia, 2008.

MARANHÃO. Maranhão em dados 2005. São Luís: SEPLAN/IMESC, 2007. 99 p.

Cerne, Lavras, v. 19, n. 3, p. 467-472, jul./set. 2013 
MARANHÃO. Zoneamento ecológico (ZEE) econômico do Estado do Maranhão: macrozoneamento ecológico-econômico, $1^{a}$ etapa. São Luís: SEPLAN/SEMA/UEMA, 2009. 42 p.

MIRANDA, G. M. Análise econômica de dois sistemas de descascamento de madeira de eucalipto. 2000. 57 p. Dissertação (Mestrado em Ciências Florestais) - Universidade Federal de Viçosa, Viçosa, 2000.

MOLICA, S. G. Produção de bimassa e eficiência nutricional de híbridos interespecíficos de eucalipto, em duas regiões biclimáticas de Minas Gerais. 1992. 84 f. Tese (Doutorado em Fitotecnia) - Universidade Federal de Viçosa, Viçosa, 1992.

NEVES, J. C. L. Produção e partição de biomassa, aspectos nutricionais e hídricos em plantios clonais de eucalipto na região litorânea do Espírito Santo. 2000. 191 p. Tese (Doutorado em Produção Vegetal) - Universidade Estadual do Norte Fluminense, Campos dos Goytacazes, 2000.

OLIVEIRA, A. C.; CARNEIRO, A. C. O.; VITAL, B. R.; ALMEIDA,W.; CORRADI, B. L.; CARDOSO, M. T. Parâmetros de qualidade da madeira e do carvão vegetal de Eucalyptus pellita F. Muell. Scientia Forestalis, Piracicaba, v. 38, n. 87, p. 431-439, 2010.

OLIVEIRA, B. Produção de carvão vegetal: aspectos técnicos. In: _. Produção e utilização de carvão vegetal. Belo Horizonte: CETEC, 1982. p. 61-73.
ORGANIZACIÓN DE LAS NACIONES UNIDAS PARA LA AGRICULTURA Y LA ALIMENTACIÓN. Situación de los bosques del mundo 2011. Rome, 2011. 193 p.

PEREIRA, J. C. D.; SCHAITZA, E. G.; HIGA, A. R. Caracterização dos resíduos da madeira de Eucalyptus dunnii como fonte de energia. Colombo: EMBRAPA Florestas, 1999. Pesquisa em andamento.

QUIRINO, W. F.; VALE, A. T.; ANDRADE, A. P. A.; ABREU, V. L. S.; AZEVEDO, A. C. S. Poder calorífico da madeira e de resíduos lignolcelulósicos. Biomassa \& Energia, Viçosa, v. 1, n. 2, p. 173-182, 2004.

SCHUMACHER, M. V. Estudo da biomassa e dos nutrientes de um povoamento de Eucalyptus globulus (Labillardière) subespécie bicostata. Revista Árvore, Viçosa, v. 22, n. 2, p. 281-286, 1998.

SILVA, H. D.; FERREIRA, C. A.; CORRÊA, R. S.; BELLOTE, A. F. J.; TUSSOLINI, E. L. Alocação de biomassa e ajuste de equações para estimativa de biomassa em compartimentos aéreos de Eucalyptus benthamii.

Boletim de Pesquisa Florestal, Colombo, n. 49, p. 83-95, 2004.

SOARES, C. P. B.; PEREIRA NETO, F.; SOUZA, A. L. Dendrometria e inventário florestal. Viçosa, MG: UFV, 2007. 95 p.

Received: April 13, 2011; accepted: March 25, 2013.

Cerne, Lavras, v. 19, n. 3, p. 467-472, jul./set. 2013 